\title{
Industrialization strategies and model for Senegal
}

\author{
Diadama Ismaila \\ PHD scholar of Industrial Economics, School of Economics, Jilin University, China
}

\begin{abstract}
After gaining independence, mainly in the 1960s, most African countries began to focus on promoting their industrialization. There was indeed a conviction among African leaders that industrialization was necessary to ensure selfsufficiency and reduce dependence on the advanced countries. Senegal also attempted at industrialization in the postindependence years but has had mixed results due to the absence of a clear policy attributable in particular to insufficient knowledge of its industrial sector. The purpose of this study is to propose strategies and an alternative model that could enable Senegal to develop its industry, based on some Asian latecomer's example, findings, industrial main obstacles and recommendations analyzed in the previous parts. It should be made right clear that there is no single best-emerging market model. In the course of development, each country follows its path based on its human, economic, and natural resources. However, whatever way it takes, most of the emerging market has put industry at the heart of its economy structural transformation.
\end{abstract}

Key Words: Senegal, Industrialization, strategy, FDI, catch-up model

\section{INTRODUCTION}

ince the Industrial Revolution, which was inspired by the advancement of technology, industrialization has been the engine of production and job creation. There is a general view that industrialization is the first economic necessity in the economic development of any country. Since 1870, entirely historic instances of achievement in financial growth and holding have managed to accumulate wealth and grow by investing in their sectors Szirmai, (2012).Industrialization is also widely regarded as a viable option for Africa's economic development. However, it is clear that Africa has missed out on the first appointment by leaving the industry to export raw materials to its natural state. In the case of Senegal, various techniques have been useful to refresh the Senegalese manufacturing part but have mixed effects due to the combination of materials, internally and externally. The Senegalese industry has suffered in recent years due to a lack of clear policy due to a lack of industry knowledge, its flexibility, and the emergence of industry trends around the world.

The findings in the above articles reveal that although the contribution of the industrial sector has decreased finished the years due to important industrialization challenges and government negligence, mechanization has had a positive impact on GDP in Senegal. And they emphasized the key elements of industrial growth. Therefore, it is recommended that in the long term there is a need for the revitalization of key industries in the country (e.g. textile industries, peanuts, and metals) and the allocation and management of existing sectors to ensure that existing sectors are adequate and suitable communication in the economy. The administration should present plans that can make a stage for overseas stockholders as it will interest overseas stockholders to participate in the state and lead to economic growth.

This study is organized as follows: the firstpart reviews the catching-up processes case studies of some Asian countries to significant main properties of their model, then we outline the significant lessons from these case studies in the second part. At the same time, the last part proposes industrial strategies and models for Senegal to catch up.

\section{Asian Industrial Models: some case studies}

There are many countries that have successfully used the "window of opportunity" to participate, such as the United States in the 19th period, Japan since the 1960s, and more recently Korea, Taiwan, Finland, and China. This part will study the case of China, Japan, and South Korea models of catch-up among this list. This choice is because we think as many authors that African countries should follow the example of Asian countries to catch up. And the case of these countries seems the most suitable for Africa in particularly Senegal.

\subsection{The catching-up model of Japan}

During the Meiji Restoration, Japan chose German industry as a benchmark at a time when per head's revenue was around $40 \%$ of Germany's. Trying to catch up with Germany was more realistic for Japan than for England. Many nations have struggled to catch up, but Japan's success was because it had chosen the right target.

Starting from a revenue status that was only one-third that of the West in the 1850s, Japan caught up fast in 50 years, becoming the first manufacturing state in Asia in 1904. Following its opening to business in 1854, the Japanese administration sent high-level missions to the Americas and Europe for closely two years, including about half of ministers from Western institutions and technology, motivated learning (Shimposha, 2000) ${ }^{1}$.The success of the Japanese economy is fundamentally a sound industrial strategy. The industrial policy model has adapted to Japan's growth model: from the

\footnotetext{
${ }^{1}$ Toyo Keizai Shimposha, 2000. Chapter 5 in -Globalization of Developing Countries: Is Autonomous

Development Possible? (Tojokoku no Globalization: Jiritsutechi Hatten waKanoka). The book won the Suntory

Prize for Social Sciences and Humanities and the Osaragi Jiro Award for Critical
} 
post-war renovation period to 1960 , from the fast-growing period to the first oil shock, and the crisis to the economic goslow in the 1990s.

After 1952, the manufacturing strategy concentrates on the rebuilding and extension of mass production industries.

The administration opted for the steel, shipbuilding, automobile, and aluminum refining sectors to stimulate economic growth as part of a national "stimulation or selfesteem" policy of the World Bank (1993). Industrial policy architects with rare natural resources and a large population

Japan should promote its manufacturing part that can compete in world markets. Komiya, Okuno, and Suzumura (1988) pointed out that this Neo-mercantilist logic dominated over neoclassical logic in the period of restructuring.

In the 1970s, the government encouraged development in knowledge-intensive industries such as electronics and semiconductors. Concretely, Japan is still a pioneer in R\&D during these decades.

The means served by industrial policy transformed a planned state economy of the post-war years into a market economy that supported Japan's gradual integration into the international economic system. The government has made different forms of intervention: funded credit and tariff encouragement, commerce safety, $R \& D$ encouragement, straight findings for foreign technology acquisitions, entry barricades, and competition regulations, and a combination of administrative consultation and coordination mechanisms (Noland) and The Package (2003).

Japan was not receiving any direct investment at that time. Manufactory building in the initial Meiji time was financed mostly from private capital, domestic savings, or joint-stock companies, or was achieved through public works. The country eagerly adopted the technology from abroad, but the bulk of the funding was Shimposa's self-created Shimposa (2000).

In the 1950s and 1960s, Japan introduced a wide range of technologies, including automobiles, machinery, and other huge businesses. Until 1988, Japan was the largest supplier in the world of technology (Odagiri and Goto, 1993). From the 1960 s onwards, as the Japanese economy raised and challenged increasing rivalry from US and European companies, personal companies started to invest heavily in domestic research and development.

Japan was quicker than other states not only in conditions of acquisition but also in conditions of developing this technology. This process of developing processes eventually became an important skill that allowed them to compete effectively with established companies in industrialized states. They have participated seriously in declining manufacturing and in obtaining internal $R \& D$ and have invested in establishing a production process. Not only did they learn quickly and apply imported technology, but they also made continuous efforts to increase the efficiency of their industries (Odagiri and Goto, 1993).In today's industrial policy debate, Japan plays a role in equity. However, many industrial policy policies adopted by the Japanese government until the 1990s did not differ from those used by other governments. Nor are we talking about countries like Korea, Taiwan, and China, which have to some extent mimicked Japanese industrial policy. But today we are talking about other developed countries, including England (mid 18th to mid 19th century), USA (mid 19th and mid 20th centuries), Germany (late 19th century), 19th and initial 20th periods) and World War II, in post-World War II France (for more details, see Chang, 2002).

\subsection{The catch-up model of South Korea}

Since 1960, the trade growth of South Korea is one of the major achievement news in the date of development. In just a few decades, it was changed from an agricultural to an industrial community that exported advanced technological goods such as TVs, cars, mobile phones, or computers.

While the Korean warfare (1950-53), which devastated the peninsula, Korea trusted heavily on US relief. Most of the economic organization set up while the Japan association was in the North (or the Republic of Korea). However, Korea promoted from a top-level of population, which dual in the below periods as an outcome of administration asset in educational and the enforcement of the proper economic policy.

In the initial 1960s, after a sequence of diplomatic turmoil, the new South Korean administration starts its five-year trade progress project. To spread the progress of export-oriented, workers-intensive trades, this administration has allocated monetary flows and tariff advantages to organizations engaging in exported initiatives, while applying hard control on imported.

Historically, the "General Park" government in the 1960s initializes fixes to spread exported, but this policy was not to convert the structure of exports. At the end of the 1960s, the Korean regime enacted wide lawson huge business and industrial. The rules promote the production of manufacturing technology and shipbuilding of 1967, the electric field of 1969, the iron and steel manufacturing of 1970, and the petrochemical business of 1970 established its commitments to the progress of these fields. Likewise, a program of assistance to heavy and chemical productions (HCI) was formally started in 1973 and was an extension to the late 1970s. The regime has guidance major financial sources and tariff advantages to this industrial, marginalizing light industrial manufacturing with high workers magnitude. He encouraged a handful of departments that had to operate well in the first five-year financial growth project.

Amsden (1989) defined the Korean administration's use of business protection, selective subsidies; exported goals (for individual departments), nationalization of the banking field, exported subsidies, and control rates. All these initiatives were 
applied to progress technical skills and finally create businesses to compete in international markets. An important factor of the policy was that in return for administration assistance and trading protection, the administration desired receivers to meet strict efficiency quality (Amsden). On the other hand, get the goals set by the Government in special by reaching their exported goals thanks to the assistance received has rewarded some.

Machine functioned by Korea was same to those used in Japan. While the exportation spread reign, basically concentrates on exportation functionality. Companies that get their exportation goals were treated well. They appreciated exceptions from importation responsibilities, tariff inducements, and privileged reach to capital. However, cost controls were upheld to1973, and the state banking field offers credits to the private field reported to the administration's preferences.

\subsection{The Chinese model of catch-up}

Meanwhile, the initialize of its strategy of conversion and openness in 1978, China's fast financial development has been a basis of worldwide attention and interest (Harris 2003, Sutter 2003-2004). Several claims that China will soon take over the US (World Bank 1997, Maddison 1998, Morrison 1998). Certainly, with the continuing economic and trade disaster since 2008, Goldman Sachs foretold that "the China economy could surpass the United State economy as the world's largest by 2027." Then their forecast three years ago was: "China is improbable to be the primary number before 2040" (Leonhardt 2008). Further hopeful about China's progress, according to a report by Value water community Coopers: "China can develop the world major economy. By 2020 , and perhaps by 2030, it will be more advanced than the US" (Price waterhouse Coopers 2010).

The Chinese pattern of progress can be seen mainly as a slow, trial, and concurrent process of industrial development, under the way of the government that conserves the marketplace. This is a technique of financial liberalization without political liberalization. Industrial development is pushed by capital (aliens invest and national reserves), employment, and skill. Marketization is presented by the making of a market external the government strategy and by a dual-track value organization without whole transfer. And globalization is getting through an exportation alignment policy.

Despite major developments, the success of the Chinese industry during the program period has declined sharply than ever before. The most obvious indication of slower ability development (World Bank, 1985, p. 110; Chen et al., 1988) notwithstanding a lengthy index of favorable conditions: unparalleled official developments in trade progress, massive Sovietized technological then financial assets, large, an increase in government spending on $\mathrm{R} \& \mathrm{D}$, primary health care and a rapid increase in primary education.
From low levels of technical skills, Chinese (government-led) firms have invested heavily in deferred sales of manufacturing and technology in their planned progress. In these sectors, China uses foreign technology to improve itself; Government efforts have been unsatisfied by the recurrent model of "luxury, importation, fail, and re-importation". Three elements seemed to contribute to this consequence: Primary, there are a difference among technologies users and technologies makers. Between 1978 and the middle-1990s, trade strategy focused on three key areas: the making of huge nationwide business groups, the acquisition of export technology, and the transformation of the nationwide study and growth (R\&D) organization. The content and aims of this policy reflect a change compared to the past, marked by the contradiction of Maoism. Until the 1980s, Great country-property enterprises (SOEs) were early users of the technology but had no motivation to develop production skills to revolutionize. Second, China businesses spend less amount integrating import technologies. They didn't have a research laboratory organization same as the R\&D laboratory organization of Japanese companies, performing standard control functions and developing or creating modern procedures. Third, certain China enterprises tried to participate in local R\&D operations after purchasing expertise from other countries to learn import technology; their efforts were very limited, specifically when competition for Japan and Korea. However, in 2005, the R\&D proportion in sold to medium and great-scale companies remained at $1 \%$ compared to developed countries, despite a steady growth since 1997.Through Freeman name, China also have "window of opportunity" unlike previous countries. When the Korean and Japanese holding model is closed, the Chinese model opens with two main features: first, modular manufacture makes lower-cost, global competition, and a variety of high-quality products. A unit is a subsection of the creation performance composition in which connections are measured and interdependence between modules is minimized as more as likely. Modular products can be parts, meetings, or machines that perform a global action using a collection of different structures blocked or elements (Chen and Liu, 2005). Whether the results of the modularization of innovation are supplier or merger, companies in developing countries can enter novelty rivalry more conveniently than ever previously. They may not be well at technical novelties; rather they can be successful and economically successful from acquiring and integrating elements. A prerequisite for companies trying to reach and participate depending on this trading framework is that they have reached the necessary technology and module plan in the home environment (LIU, 2005). Second, in terms of global technology trade, Chinese companies are using international technology to produce new products faster. Global technology trading can be an additional burden or opportunity, depending on whether the company in the game is making a technical effort to support success, adaptation, assimilation, and technological development (Archibuchi, 2003). These are the basis for Chinese firms to take over their models and differentiate their models from other firms from Japan, Korea, and other latecomers. 
Table 1: The comparison of Japanese and Chinese catching up model

\begin{tabular}{|c|c|}
\hline Japanese Catching up model & Chinese catching up model \\
\hline $\begin{array}{c}\text { Technology importation is } \\
\text { significant }\end{array}$ & $\begin{array}{c}\text { FDI and diffusion are welcomed and } \\
\text { the globalization of technology } \\
\text { permeates }\end{array}$ \\
\hline $\begin{array}{c}\text { FDI and globalization technology } \\
\text { have a limited impact }\end{array}$ & Modularization \\
\hline In-house R\&D is most important \\
suppliers is crucial
\end{tabular}

Source: Van-ha NGUYEN 2010

The innovation of the product, based on the acquisition of international technology in China, is very dissimilar from the new structure, which is the foundation of competition for Japanese organizations in the trade industry. As reported to Fujimoto, there are two main kinds of architecture in production: sectional construction and integrated construction. In sectional construction, the method of links between parts is rated for secure contact. For example, desktop pc is a common creation in which international standard elements from many departments are easily integrated. Indifference, in critical construction, the difficulty of connections is acknowledged and developments are gained by multiple tests and bugs. For case performance, comfort, fuel economy, safety, etc. Automobiles must be built from basic materials if multiple purposes are being achieved at the same time. In general, modular architecture is well suited for fast outcomes at low cost, while the critical design is ideal for the highest quality in the long run.

\section{INDUSTRIAL LESSONS FROM THE COUNTRIES CASE STUDY}

The catch-up experience for these examples of countries studied above shows some prerequisites that low-income countries need to develop their industry.

\subsection{More access to FDI}

Meanwhile, in 1990, alien direct asset (FDI) has been the main overseas investment in emerging states. During the 1960s and 1970s, several developed states became dilemma of foreign direct investment and frequently taken action to discourage it. At that while, these suspicions were often wellfounded, due to the recent history of expansionism in many states and the irritating attitude of some overseas stockholders to gain administrative rights and make huge profits using weak political and legal systems. From the middle-1980s, this behavior started to transform, and emerging states required attracting foreign direct investment to finance investments, create trades, and import knowledge and ideas to other countries.
Foreign direct investment is slight than to local assets, but its portion has increased over the last two decades, according to the "Global Investment Report", p4: only over 10\% of total investment in emerging states in 2003, related to around $2 \%$ in 1990. FDI is vital to the economy of a developing country. They are valued because of their sustainable characteristics and their relatively larger growth-training effects than any other type of investment. Perceived as a key vector in the economic development process, FDIs reward the economy with several positive effects such as: increasing the level of private capital stock, stimulating competitiveness in the local market, creating jobs, and increasing the stock of knowledge by providing new equipment and transferring know-how to name just a few.

\subsection{Use of comparative advantage in the industrial sector}

Lin (2011) and Monga (2011) examine the type of new growth and display that an emerging state can reach strong development within a few periods and reach developed countries by developing industries suited to its comparative benefits determined by its framework and use. They point out that due to the comparative advantages of less-income countries and growing economies, when these countries develop their industries, there will be a large gap for lessrevenue states. Second, it may use this chance to reap the possible benefits of a late start to industrialization and drive strong progress and lack decrease.

In a current study titled The Pioneering Dragon Phenomenon: New Chances for Capture in down-Salary States, Justin Yifu Lin, Chandra Vandana and Yan Wang showed how new monetary growth goes hand in hand with structural change as countries move from agricultural to industrial. The economy and how these developments occur through continuous industrial and technological processes. They show that all states that have achievement industrialized in Europe, North America, and East Asia since the eighteenth century have two things in common: they have enjoyed their comparative advantage; and took advantage of the newcomers themselves to emulate the industrial modernizations of wealthier countries. But for a rare oil-exporting state, no state has become a high-salary country deprived of industrialization. In over-all, there is one close and optimistic relationship among Gross domestic product per capita progress and value-increase growth in the industrial part. Middle-income states wealthy in land or naturally sources without relying on a large manufacturing sector have rarely managed to sustain their growth.

\subsection{Modular vs. Integral model}

China's experience of participation illustrates a catch-up pattern based on the global worker divide between organizations, linked produce and manufacture expertise, and knowledge source. In dissimilarity, the Japan model is foundation on a significant project. This model is separated into three stages: technical introduction, knowledge/familiarity/moderation, and internal $\mathrm{R} \& \mathrm{D}$. 
Deprived of internal strength, companies in holding countries cannot understand imported technologies and create new and growing innovations (Odagiri and Goto, 1993).

\subsection{Access and transfer of new industrial technology}

Developing countries need access to new technology to innovate. Today, companies in developing countries have access to cutting-edge technologies to undertake product innovations much faster than Japanese and Korean firms, which must pause for knowledge to develop before they can professionally import and gradually revolutionize. Similarly, recent studies on foreign direct investment flows contradict the proposal of the creative life round concept (Cantwell, 1997). Several new types of machinery were instantly transferred to emerging countries for mismanagement, and the research and development laboratories of multinational companies in developing countries are developing many new technologies. Nowadays, data knowledge has different rules of the games to catch up. Perez and Soete (1988), while examining the "windows of opportunity" for emerging country companies to grow, point out that outside academia study could present a new knowledge scheme and thus expose a new "window of opportunity".

In addition to access to the latest technology, institutional simulation of trained personnel and innovation are also required. The USA, for example, was able to learn about the "spirit of science" and supported the development of technology from England. Thus, a usual of domestic standards and schemes were additional that led to a work-concentrated, cost-effective system of production and a measure of the extent to which America was able to feat its rich natural resources and big national markets (Abramovitz and David), 1994). From the very opening, American inventors adapted and redesigned British technology to adapt to American conditions. By the end of the 19th period, American technologists and experts were increasingly isolated, producing more than those in Britain, emerging new procedures and goods in many businesses.

Technological advances sometimes come from the study of other countries, as illustrated by the example of India and semiconductors. Joining Silicon Valley, the Indian Diaspora gained the knowledge that India brought back to its country to develop the electronics industry that is growing well today.

\subsection{Population flows}

The examples of the recently successful catch-up process are based on the existence of cross-border population flows. These flows concern both citizens of the country emigrating to study in industrialized countries, and returning home and qualified people from other countries who come as advisors or experts in the country in catch-up. As an example, it was British technicians who brought textile production techniques to the United States in the 19th century. The Japanese industry also developed under the impetus of technical advisors from abroad, while the Japanese returned home after studying
Western methods. These cross-border movements of skilled labor have also intensified, thanks to the action of companies and universities. Multinational companies have played a growing part in this transnational knowledge procedure. Thus, new Japanese automotive and electric companies instituted close association with companies in the United States and Europe during the post-war period. Singapore's development has also been largely led by subsidiaries of multinational companies, while Korean and Taiwanese companies have acquired their expertise by working for American and Japanese companies. Similarly, in its recent report on technological development in developing countries, the World Bank stresses the influence of Diaspora on the diffusion of technology.

From the above analysis of those catch-up countries example, countries could develop supporting industries by using their Comparative advantage businesses, interest more foreign direct investment and inspire skill spillovers and innovation for industrialization. Also, they must be more open in order to get a "window of opportunity" then build manufacturing basis and face international rivalry.

\section{INDUSTRIAL STRATEGIES AND MODEL FOR SENEGAL}

In the 1950s and 1960s, Asian countries such as South Korea or Taiwan had levels of development almost similar to those of African countries like Ghana, Senegal, or Nigeria. The following decades saw the "dragons" of Asia start a forced march of economic catching-up process of the developed world, while these African countries have remained behind.

For the Senegalese economist Mamadou Moustapha Kassé in his book "The industrialization of Africa is possible: what model for Senegal?" Africa is introduced into the global economic game through the geostrategic of raw materials. By comparing bringing the continent's economic, financial, and technological interests to those of the major emerging countries, it is possible to build or rebuild competitive industrial policies.

\subsection{Strategy to attract more FDI in Senegal}

Meanwhile 1990, foreign direct investment (FDI) has been the major foreign investment in emerging countries. During the 1960s and 1970s, many emerging countries became dilemma of foreign direct investment and frequently took phases to deter it. At that period, these suspicions were often wellfounded, due to the recent history of colonialism in many countries and the sometimes irritating behavior of some foreign investors to gain administrative rights and make huge profits using weak political and legal systems. From the mid1980s, these arrogances started to transform, and emerging countries were required to attract foreign direct investment to finance investments, create jobs, and import technology and ideas to other countries.

Foreign direct investment is minor likened to national assets. However, its part has increased over the last two periods, 
according to the "World Investment Report": it accounts for more than $10 \%$ of total investment in emerging states in 2003, likened to about $2 \%$ in 1990 . Indeed, Senegal is home to a large stock. Predominantly French FDI ratio is likened to the rest of the region. Reported to the 2018 African Asset Index, Senegal ranks tenth among African countries that attract the most foreign direct investment (FDI). The government has an energetic rule to inspire foreign direct investment influxes.
Reported to the 2018 UNCTAD Asset Statement, FDI in Senegal increased from US\$276 million in 2012 to US\$532 million in 2017.Total FDI stock was USD 4.8 billion $(31.5 \%$ of GDP) at the end of 2017. Among the leading investors in the country are France, Morocco, Indonesia, and the United States. Foreign Direct Investments grew significantly between 2000 and 2018.

Figure 1: Total FDI flows from 2000 to 2018 in millions of USD

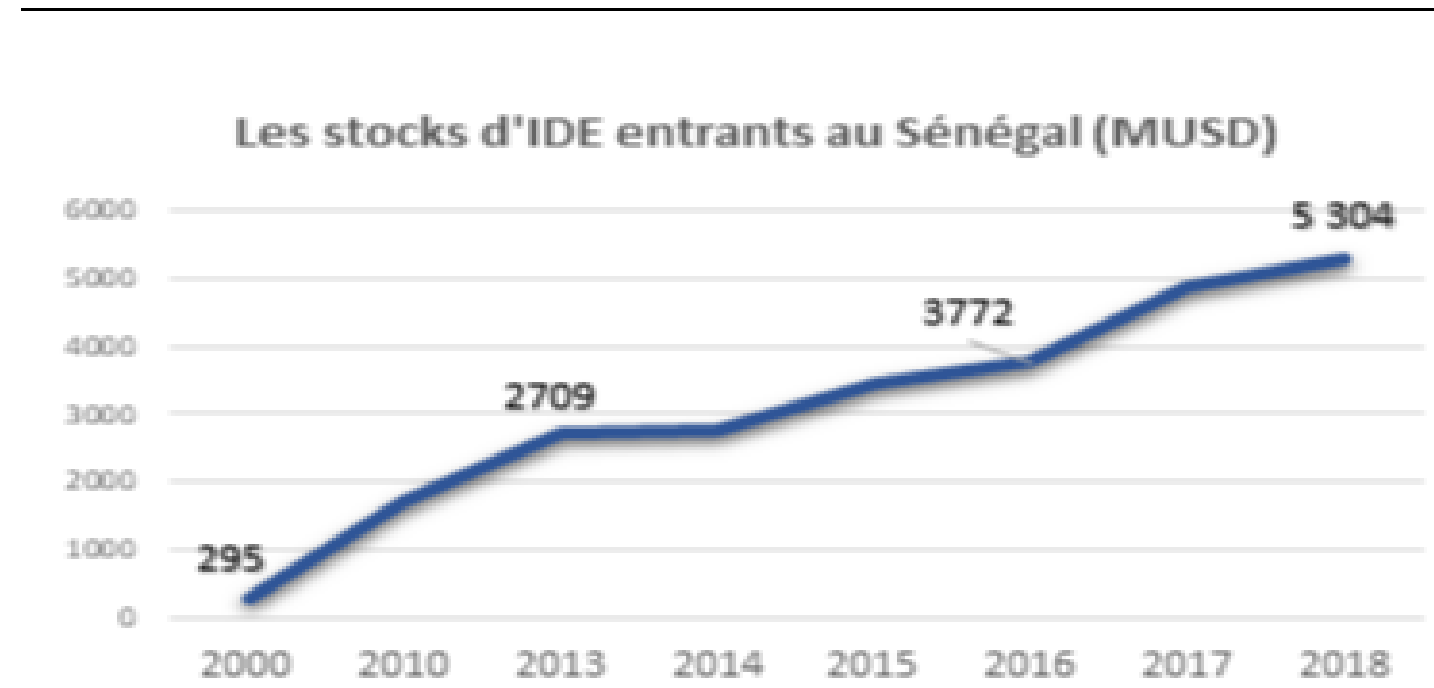

Source: UNCTAD database, 2018

Senegal is ranked 141st out of 190 countries in the World Bank's Ease of Responsibility Commercial 2019 report, down one percent from the previous year. Within the scope of the Business Environment and Competitiveness Reform Program, significant improvements were completed in the procedure of occupation making and contract implementation. The new exclusive economic region should encourage assets. The administration accepts overseas assets, but possible depositors face barriers, with highly transparent regulations and high issue costs. There is no legal discernment against companies owned or operated by foreigners, and in most sectors, there is no barrier to foreign investors is fully owned. Senegal's strengths include competitive production costs, a skilled workforce, strategic geographic location, excellent international and regional political relations, and a competitive economy. To appreciate the efficiency of the investment, the Incremental Capital Output Ratio (ICOR) is often used. It is the marginal coefficient of capital obtained by the ratio between the annual investment and the annual change in GDP. A high ICOR value is therefore not desirable, as it reflects a small change in production despite an increase in investment. In other words, it would indicate inefficiency in investment efforts. According to Vanek and Studenmund (1968), the desirable level of ICOR for developing countries is around 3. An ICOR above three, therefore, reflects inefficient investment. The table below presents the situation in WAEMU countries

Table 2: Incremental Capital Output Ratio (ICOR) between 1981-2014

\begin{tabular}{|c|c|c|c|c|c|c|c|c|}
\hline \multirow{3}{*}{ Benign } & Burkina & \multirow{3}{*}{ Ivory coast } & Guinea & & & & & \\
\hline & \multirow{2}{*}{ Faso } & & \multirow{2}{*}{ Bissau } & & & & & \\
\hline & & & & & & & & \\
\hline 4,7 & 4,2 . & 5,9 & 6,5 & 5,9 & 8,2 & 6,5 & 5,6 & 5,8 \\
\hline
\end{tabular}

Source: World Bank, taken over by Soumaila (2014)

This table shows the lack of efficiency of investments in all states of the West African Economic and Financial Union (UEMOA). As a matter of fact, the coefficient values are higher than the critical value for all countries. The average value of the ICOR is 5.8. It appears that Senegal (with 6.5) is one of the countries where the efficiency of investment is less important. 
FDI is of crucial importance to the economy of a developing country like Senegal. They are valued because of their sustainable characteristics and their relatively more significant growth-training effects than any other type of investment. Perceived as a critical vector in the economic development process, FDIs reward the economy with several positive results. We can quote the growth in the level of private wealth standard, the stimulation of competitiveness in the local market, the creation of jobs, and improvement of the stock of knowledge by providing new equipment and transferring know-how.

As Daniel Sessi recalls in a brilliant analysis for "Africa of Ideas," ${ }^{2}$ the African continent can attract FDI not only based on its resources and its local market, but also by improving the business environment ${ }^{3}$. This analysis is widely shared by the majority of economists and experts in the field ${ }^{4}$.

The ambivalence and efficiency towards FDI required the definition of a global and shared strategy for improving the attractiveness of Senegal. Various key factors of success can be apprehended, such as operational and robust governance, a vision, relevant territorial marketing, and investment agency, etc.

\subsection{Industrial strategies and model}

Senegal can learn from important Japanese production. It should try to be a reliable partner of emerging countries in excellent production with Japan and other industrialized nations, which are important manufacturers. It is an honest behavior about producing with arrogance, skill, and commitment and how to achieve high performance in terms of long-term profit. Japan is an integrated manufacturing country with advanced knowledge, advanced salaries, and the number of adults searching for partners in an emergent country. The reality is that in developing countries, integrated manufacturing will not be fully developed by simple processes. That's why Japan requirements a small, emergent country as a trusted partner in integrated industrial. Senegal can also learn from China about the rapid increase in production volume. China has a huge quantity of directors, researchers, technologists, and untrained laborers, abundant manufacturing equipment, a high surface of knowledge supported by a long date of mechanization, and a dense system of Chinese foreign enterprises. Senegal can build productive relations with China and practice cheaper Chinese contributions to its benefit. The right position requires a clear understanding of China's leading and under performing areas.

Senegal must also rely on sub-regional and continental integration with other African countries to get out of the

\footnotetext{
${ }^{2}$ AFRICA: Attraction of Foreign Direct Investments - on

http://terangaweb.com/africa-attraction-investment- direct-foreigners /

${ }^{3}$ Morisset, J. (2000), "Foreign Direct Investment in Africa: Policies Also

Matter," Transnational

Corporations 9 (2): 107-25

${ }^{4}$ See the World Investment Report (UNCTAD) -

http://unctad.org/en/PublicationsLibrary/wir2013overview_en.pdf
}

narrowness of domestic markets. The Senegalese Professor Demba Moussa Dembélé "assumes that the issue of industrialization must be at the heart of the agenda of the African Union and the different sub-regions of the continent. However, given the considerable changes in the international environment, the chances of success of this industrialization can only be envisaged in a sub-regional or continental context ". It will, therefore, be necessary to build on strategic partnerships by using geographical proximity between the continent and its neighboring markets to encourage coproduction operations and develop local industry."

However, Senegal has some country-particular advantages, such as easy access to the Atlantic Ocean, proximity to rich markets (EU and USA), or accessibility of basic manufacture materials (cotton, leather). In addition, Senegalese foreign exporters are not worried about major tradebarriers due to favored trade deals (especially the Everything except Arms program and the African Development and Chance Act). Senegal is also associate of the Economic Public of West African States (ECOWAS).

In addition, if Senegal uses FDI as its driving force, it should point out those industries that have the greatest potential in its economy (industries that are relatively lucrative).

Using the concept of revealed comparative advantage, we identify the manufacturing and industrial sectors with the greatest benefit to Senegal's rapidly growing economy. The benchmark of the comparative benefits expressed (RCAs) is a value of 1 .

Table 3: Competitiveness of manufacturing activities (RCA-Senegal) in 20002016

\begin{tabular}{|c|c|c|c|c|c|}
\hline & 2000 & 2004 & 2008 & 2012 & 2016 \\
\hline $\begin{array}{c}\text { Natural resources: } \\
\text { agro }\end{array}$ & 2,655 & 1,526 & 1,259 & 1,591 & 1,548 \\
\hline $\begin{array}{c}\text { Natural resources: } \\
\text { others }\end{array}$ & 2,633 & 4,026 & 4,971 & 3,153 & 3.482 \\
\hline $\begin{array}{c}\text { Low technology: } \\
\text { textiles, clothing } \\
\text { and footwear }\end{array}$ & 0,173 & 0,171 & 0,181 & 0,170 & 0,128 \\
\hline $\begin{array}{c}\text { Low technology: } \\
\text { other products }\end{array}$ & 0,433 & 0,394 & 0,511 & 0,535 & 0,527 \\
\hline $\begin{array}{c}\text { Medium } \\
\text { technology: } \\
\text { automobile }\end{array}$ & 0,031 & 0,065 & 0,111 & 0,148 & 0,078 \\
\hline $\begin{array}{c}\text { Medium } \\
\text { technology: } \\
\text { processes }\end{array}$ & 0,988 & 1,439 & 0,722 & 0,535 & 0,648 \\
\hline $\begin{array}{c}\text { Medium } \\
\text { technology: } \\
\text { engineering }\end{array}$ & 0,114 & 0,129 & 0,182 & 0,195 & 0,137 \\
\hline $\begin{array}{c}\text { High technology: } \\
\text { electronic and } \\
\text { electrical }\end{array}$ & 0,071 & 0,042 & 0,061 & 0,065 & 0,041 \\
\hline $\begin{array}{c}\text { High technology: } \\
\text { others }\end{array}$ & 0,208 & 0,259 & 0,244 & 0,138 & 0,093 \\
\hline
\end{tabular}

Source: Authors' calculations from UNCTAD

This table shows that only natural resource-based manufactured products have RCAs above the reference value. 
This result highlights Senegal's advantage in the production of agro-manufactured products and other natural resource-based manufactured products such as the chemical industry sector and the cement sector, gas products, etc. These results confirm the results of the study on relative benefit, financial construction, and development: the case of Senegal's Jiri Sejkora and Ondrej Sankot (2017). Indeed, the results using the RCA concept show that Senegalese manufacture and exportations are mostly associated with substances (e.g. inorganic biochemical component perfumery, pesticides, soaps, etc.) and industrial things (e.g. lime, minerals, cement, and invented construction resources). Senegal generally cannot export high-value-added manufactured products. To promote industrialization and development, Senegal should concentration mostly on the above-mentioned trades where the economy presently has RCA. Senegal should also capitalize on its natural resources to create new value-added activities through strategic partnerships with key players. We think about developing its mining sector, oil, and gas, which can become the driving sectors of the Senegalese economy.

The modern history of Senegalese mining times back to the $1940 \mathrm{~s}$ then 1950s, with the opening of two great orthophosphate mines at Taiba and Lam-Lam in the Thies region, 70 kilometers from the capital, Dakar. These significant phosphate credits have preserved Senegal's economic success for decades. Senegal's sedimentary basin is also rich in other minerals, with zircon, ilmenite, titanium, limestone, attapulgite, peat, and natural gas. The lower Kedougou rocks in the southeastern portion of Senegal (at the crossroads between West African countries) contain significant amounts of gold (for example, Sabodala, Niakifiri, Massawa, Goulouma, Masato, and Niamia), iron ore, marble, and other valuable materials such as uranium., copper and chrome make this province an important exploration area. Furthermore, Senegal has also explored the sector of gas and oil recently discovered. Senegal has been interested in oil and gas for over 60 years. But it is only in the last five years that it has come to the fore as a potential world-class hydrocarbon basin. In2014, Cairn Energy and its partners drilled many wells in the SNE field in the south. In the north, Kosmos has discovered vast gas reserves that straddle the northern Senegal-Mauritania border and. These recent discoveries will be exploited from 2020 to predict optimistic projections for the overall industrial sector. Senegal's oil and gas discoveries have the potential to transform the country radically. These successful explorations in the country have put a glow on the legal regime for oil and gas and the relevance of the regulatory framework to support the significant scale investment that such discoveries will require. Senegal's power part has currently received a big improvement after US and UK businesses announced their oil and gas results off the shore.

Senegal has managed to thrive and develop the area's quantity one commercial center. It can nowadays become the continent's new energy hotspot thanks to new sea discoveries. However, the main challenge will be to avoid the so-called resource curse that has tormented several African states rich in natural resources.

Based on the above analysis and the main findings in the previous sections, we suggest that Senegal can learn to capitalize on its comparative advantage industries, attract more FDI and encourage technology diffusion and innovation through the following strategies:

\section{Promote FDI to make the country more attractive}

The country should be made more attractive concerning FDI. Today, in the context of free trade, small external openings such as free trade and investment are no longer sufficient to attract large flows of FDI. The Senegalese government should work in cooperation with foreign investors; listen carefully to their needs, set agreed targets for technical transfer and procurement in the internal market, design coherent support policies, and so on. At the same time, Senegal would also benefit from improving the legal system, including foreign investment law, streamlining licensing procedures, and stabilizing rules and regulations for foreign investors.

\section{* Promote a better investment}

The aim is to make industrial decentralization real by increasing public investment in the territories, promoting areas of industrial specialty with the comparative advantages of the regions, and making the installation of the industrial platforms planned in the first phase of the PSE a reality. In fact, PSE announced the establishment of industrial platforms, including the Diamniadio particular Financial Sector, which should be a multifunctional stage for most revenue-producing activities (manufacturing, skills, clothing, goods, infrastructure, etc.). This is portion of the wish to inspire businesses to move from the capital and expand their businesses and attract new investors. Public investment is a significant determinant of private investment. The State of Senegal has made a lot of effort in the development of management structures and support for the industry sector (DEPME, FONSIS, FONGIP, BNDE, APROSI, etc.). However, the diagnosis shows that the knowledge and accessibility of these structures are quite problematic for many companies and industries. For this reason, strengthening the dynamism of these structures is a strong recommendation.

\section{Promote better trade for the industrial sector}

This is to promote the policy of protection of baby industries, to promote exports of manufactured products with Medium and High Value Added. Senegal should use targeted strategies to create superior localization advantages and reduce the costs of doing business. To achieve this goal, it must develop its skills (production management, marketing, and engineering), infrastructure, support institutions, efficient community facilities, and good organization of manufacturing parks and industrial free zones. The national private sector plays a significant role in the transfer of new technologies and skills. Therefore, policies that strengthen domestic private 
enterprises and links between foreign and domestic sectors are encouraged.

\section{Improve the business environment}

Also, it will be necessary to reduce the tax burden for businesses and simplify tax procedures; promote the formalization of companies; continue and deepen the reforms initiated under the PREAC.

\section{* Strengthen human capital (through a diversified training offer)}

The emphasis should be on promoting social investment, which is a significant element of production. This implies the existence of an educational system capable of providing human resources that meet the requirements of the labor market. Strengthening social capital, through a diversified training offer, a better quality of education and training, and a better training-employment match is crucial in the competitiveness of the industry sector.

Senegal would also benefit from reinventing its educational system so that it becomes capable of continually adapting to changes in the world and developments in the international environment. Senegal is endowed with a very young population and should adopt the approach of a nation keen to garner its demographic dividends by emphasizing relevant education and training. To do this, it must be free from an educational framework in which cohorts of students are directed to universities each year to take courses, many of which have no impact on the current needs of the labor market or the imperatives of competitiveness of the country's economy. The current education system needs to be coordinated with strategies to give pride of place to the needs of the business. The vocational training system needs to be reevaluated, with reforms that dispel the "myth of the university".

\section{Facilitate access to credit for businesses, including} long-term loans

Access to credit is problematic, and loans granted to enterprises are for the majority of short-term credits that do not allow structuring investments. Facilitating access to credit is thus crucial in improving the competitiveness of the industry sector.

\section{Promote research development and technological innovation}

Promoting research and development and innovation is essential for the continuous adaptation of the needs of the market and the supply of businesses, but also the increase in productivity levels. It is, therefore, essential for industrial competitiveness. A competitive and sustainable industry is fundamentally based on technology and innovation. Which, levers mostly contribute to the transformation by an added value. It appears that $80 \%$ of exports in the world are made up of manufacturing products. This is why Senegal must respond to technology and innovation. But to do this, we must remove among other weaknesses of the Senegalese technological system that are lack of funds to finance innovation, very high costs of innovation, very high perceived economic risks, organizational rigidities, lack of information on technology, rigidities of rules and standards. It is also necessary for the field of technological innovation to improve the industrial and managerial skills of small entrepreneurs and artisans (process, management, marketing organization), strengthen the capacities of SMEs / SMIs for better exploitation of industrial property and also create a Center of Excellence for Science, Technology, and Industry.

\section{Solving the vital issue of energy and infrastructure}

The Energy Sector strongly supports economic development, reduction of social and spatial inequalities. That is why Senegal needs to improve its infrastructure, especially the development of electricity supply. The biggest problem is that the energy industry is underdeveloped independently, which is a major obstacle to industrial growth. Through its Emergency Policy, Senegal will need to ensure broad and reliable access to cheap energy. It must also provide security of property and infrastructure. Improvement source and monetary presentation of Senegal Electric Business (SENELEC) can be a major challenge. Privatization can be a solution that attracts investors. However, there has been a surge in private equity in the infrastructure sector due to a number of factors, including the wish to entice overseas investors. This policy has been very successful in the transport sector and did not yield the expected results. Causes need to be considered before making any other specific application.

\section{* Build partnerships and reduce information gaps}

Global value chains represent the current trend of international companies. Senegal should seize the opportunity for international experience and partner with international organizations to develop industrial links between local and multinational companies. Experience from other countries shows that success in developing relations depends on the immediate response of the government to the changing business environment (Japan), support from leading companies (Korea, Taiwan), or technical and financial support from the government (Japan and Taiwan). The government should also leverage information technology to bridge the knowledge gap between local businesses and foreign companies. Finally, in order to meet today's needs and catch up with developed countries, industrial policies should create industrial societies in parallel with information societies. This means that policies should not only aim to reduce costs and improve the quality of industrial infrastructure, but also maintain an environment conducive to innovation based on a network of companies, universities, and research institutions.

\section{CONCLUSION}

The main aim of this paper is to define the convergence models of some Asian latecomer countries in order to find out the determinants that led them to reach this level of growth 
and then propose an alternative model of catch-up for Senegal. Finally, we propose some industrial strategies such as the promotion of FDI, innovation, and countries partnership for Senegal to catch up. This will enable Senegalese companies and the country as well to connect with the broader global economy and take advantage of strategies such as new technologies, skills, and knowledge. From that Senegal will enable to achieve the strategic goal of industrial catch-up. We will also advocate the development of Senegal's comparative advantages but also the sector of mines, gas, and oil as well.

Notice these strategies are also based on the industrial obstacles and the other findings in the previous parts.

Figure 2: A Proposed Model for Senegal's catching-up process

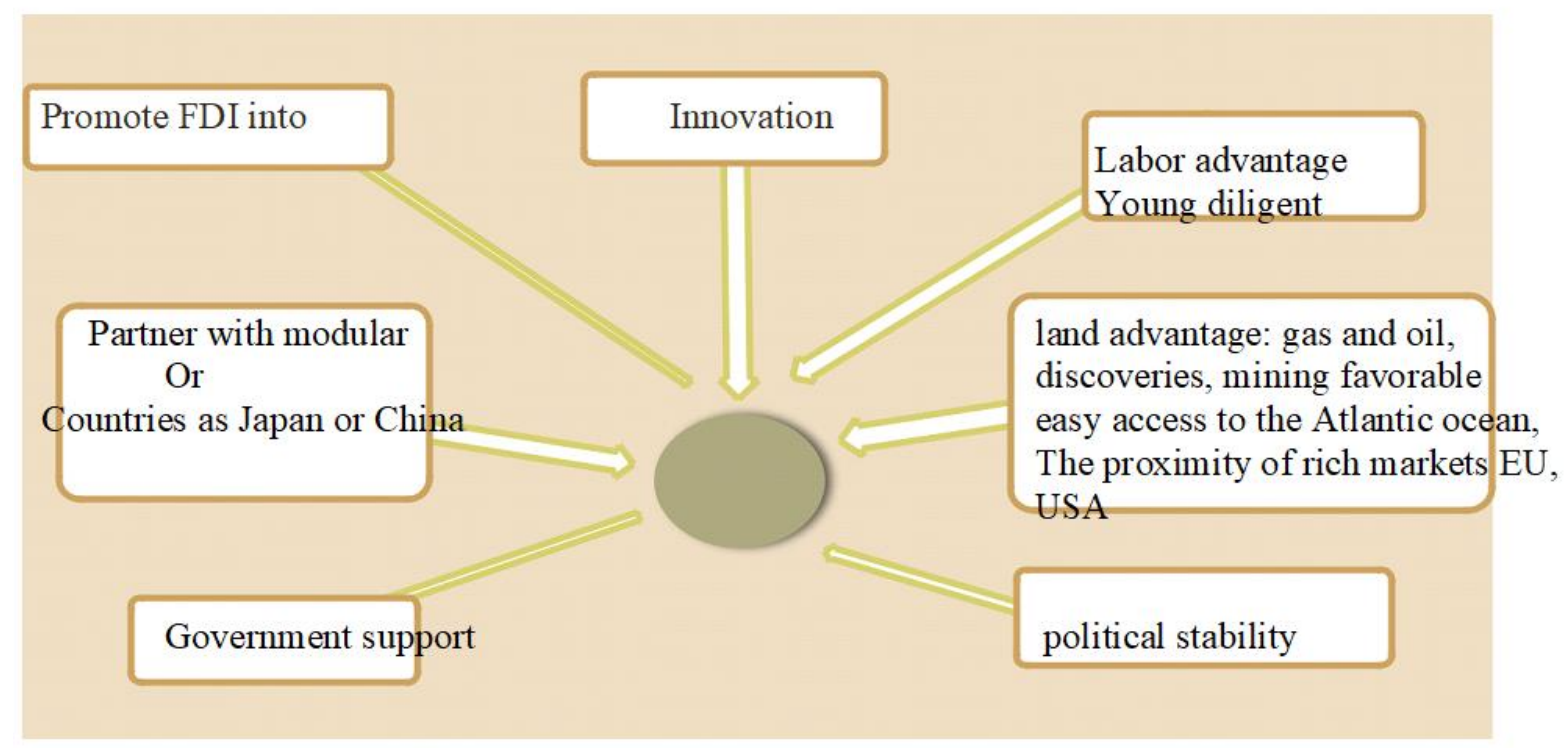

\section{REFERENCES}

[1] Abbott, L. F. (2003). Theories of industrialisation and enterprise development. London: Good Book.

[2] Adejugbe, M. A. (2004). "Industrialization, Distortions \& Economic Development in Nigeria since1950" in M. O.A. (ed.), Industrialization, Urbanization and Development in Nigeria 19501999, Lagos: Cocept Publications Ltd.

[3] African Development Bank, (2008). African Development Report 2007. African Development Bank, Abidjan

[4] AICD (Agence Nationale de la Statistique and ICF International) (2012). '2010-11 Senegal Demographic and Health and Multiple Indicators Survey: Key Findings'. Calverton, MD: ANSD and ICF International

[5] ANSD, Rapport provisoire de l'enquête sur l'état des lieux de l'industrie au Sénégal, (2017).

[6] Bolaky, B. A. (2011). The role of industrialisation in economic development: theory and evidence.UNCTAD.

[7] Diagne, Y.S. and fall, A. (2007). Impact des infrastructures publiques sur la productivité des entreprises au Sénégal. Direction de la Prévision et des Etudes Economiques, août 2007.

[8] Diop M. M. (2015). "Quels secteurs pour quelle croissance économique au Sénégal? ».

[9] Kaldor, N. (1967), Strategic Factors in Economic Development, Cornell University Press, Ithaca, NY.

[10] Lee, S., Nam, Y., Lee, S., \& Son, H. (2016). Determinants of ICT innovations: A cross-country empirical study. Technological Forecasting and Social Change, 110, 71e77.

[11] Lin, J.Y. \& Monga, C., (2011). Growth identification and facilitation: The role of the State in the dynamics of structural change. Development Policy Review 29(3). 259-310. https://doi.org/10.1111/j.1467-7679.2011.00534.x.
[12] Mamadou Moustapha Kassé, (2013). L'industrialisation de l'Afrique est possible: quel modèle pour le Sénégal? L'harmattan, Novembre 2013.

[13] Mandara, (2018). "Topic: Appraisal of the Impact of Industrialization on Economic Growth in Nigeria."

[14] IOSR Journal of Business and Management (IOSR-JBM) 20.1 (2018): 01-10.

[15] Mbaye A. A., (2006). «Étude sur la prise en compte de la politique commerciale dans les stratégies de développement: CAS du Sénégal ».

[16] Mbaye A.A, (2002). " An Industry Level Analysis of Manufacturing Productivity in Senegal », Africa region Working paper Series $\mathrm{N}^{\circ} 41$

[17] Nguyen, Van Ha. (2010). An alternative strategy for catch-up economy in Vietnam, a lesson for developing countries. Journal of The institute of Business and Economic Research Inha University. (ISSN 1225-4703).

[18] Rapport DGPPE, (2017). "Quelles stratégies pour le secteur de l'énergie au Sénégal? ».

[19] Republique Du Senegal (2014), " Plan Senegal Emergent ». Republic of Senegal/UNDP (1997). 'L'industrie Sénégalaise de 1992 à $1995^{\prime}$. Dakar: Republic of Senegal/UNDP

[20] Solow, R. M. (1956). A contribution to the theory of economic growth. Quarterly Journal of Economics, 70 (1)Todaro, M. P. \& Smith, S. C. (2011). Economic development (11th Edition). Edinburgh: Pearson Education Limited The World Bank (2012), World Bank Development Indicators. Washington D.C.

[21] Szirmai, A., (2012). Industrialisation as an engine of growth in developing countries 1950-2005. Structural Change and Economic Dynamics 23 (December (4)), 406-420. 
[22] UNIDO, (2004). "Industrialization, Environment and Millennium Development Goals in Sub-Saharan Africa," Industrial Development Report.

[23] UNCTAD (2011). Statistical database. Retrieved from unctad.org.

[24] World Bank (2005) Doing Business in Africa, Oxford University Press
[25] World Bank (n.d.). 'Enterprise Survey'. Available at: /www.enterprisesurveys.org/.

[26] World Bank, World Development Indicators (Washington, DC: World Bank) 